\title{
Vegetable Waste Inclusion in Broiler Diets and its Effect on Growth Performance, Blood Metabolites, Immunity, Meat Mineral Content and Lipid Oxidation Status
}

\section{-Author(s)}

\begin{tabular}{|c|c|}
\hline aza A' & https://orcid.org/0000-0002-8873-9728 \\
\hline lussain J' & https://orcid.org/0000-0002-4837-375X \\
\hline ussnain $\mathrm{F}^{\prime}$ & https://orcid.org/0000-0001-5296-8046 \\
\hline Zahra F" & https://orcid.org/0000-0001-7806-2007 \\
\hline Mehmood S' & https://orcid.org/0000-0001-8229-7343 \\
\hline Mahmud A' & (iD) https://orcid.org/0000-0002-2106-4113 \\
\hline Amjad ZB' & $0-0001-5435-0004$ \\
\hline Khan MT' & os://orcid.org/0000-0002-4734-3428 \\
\hline Asif $M^{\mathrm{v}}$ & tps://orcid.org/0000-0003-2869-1272 \\
\hline Ali Uv & ttps://orcid.org/0000-0003-3006-4075 \\
\hline Badar $\mathrm{IH}^{\vee}$ & https://orcid.org/0000-0001-7352-9712 \\
\hline Vadeem M"II & https://orcid.org/0000-0002-6548-7978 \\
\hline
\end{tabular}

Department of Poultry Production, Faculty of Animal Production \& Technology, University of Veterinary and Animal Sciences, Lahore-Pakistan Department of Clinical Medicine and Surgery, Faculty of Veterinary Science, University of Veterinary and Animal Sciences, Lahore-Pakistan Department of Dairy Technology, Faculty of Animal Production \& Technology, University of Veterinary and Animal Sciences, Lahore-Pakistan Department of Animal Nutrition, Faculty of Animal Production \& Technology, University of Veterinary and Animal Sciences, Lahore-Pakistan Department of Meat Science and Technology, Faculty of Animal Production \& Technology, University of Veterinary and Animal Sciences, Lahore-Pakistan

Planning and Development Division, Pakistan Agricultural Research Council, Islamabad, Pakistan

\section{Mail Address}

\section{Corresponding author e-mail address}

Faisal Hussnain

Department of Poultry Production, Faculty of Animal Production \& Technology, University of Veterinary and Animal Sciences, Lahore, 54000, Pakistan.

Phone: 00923014674474

Email: faisal.hussnain@uvas.edu.pk

\section{-Keywords}

Alternative feed, Commercial feed, Meat evaluation, Poultry production.

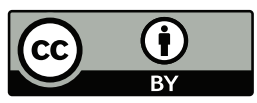

Submitted: 18/July/2018

Approved: 31/December/2018

\section{ABSTRACT}

The aim of present study was to evaluate the effect of feeding vegetable waste (VW) to broilers on their growth performance, serum chemistry, immune status, meat mineral content and lipid oxidation status. For this purpose, 100 one-day-old chicks (Cobb 500) were acquired from a commercial hatchery and allocated according to a completely randomized design into five dietary treatments with four replicates of five birds each. The dietary treatments included: T1 (100\% commercial feed (CF) + 0\% VW), T2 (75\% CF + 25\% VW), T3 (50\% $\mathrm{CF}+50 \% \mathrm{VW}), \mathrm{T} 4$ (25\% CF $+75 \% \mathrm{VW})$ and T5 (0\% CF + 100\% VW). Experimental birds were subjected to dietary treatments from 5 to 7 weeks of age. At the end of week 7 (49 days), eight birds with uniform average body weight were selected per treatment (2birds/replicate), kept off-feed for $4 \mathrm{~h}$ and then manually slaughtered according to the Halal method to collect data for serum chemistry, meat minerals and lipid oxidation status. The results indicated better meat lipid oxidation status $(p \leq 0.05)$ and lower meat mineral content $(p \leq 0.05)$ when birds fed VW at 25, 50, 75, and $100 \%$ of the diets compared with $100 \%$ commercial feed. On the other hand, blood chemistry and antibody response parameters did not respond $(p>0.05)$ to dietary intervention. In conclusion, dietary inclusion of vegetable waste had positive influence on meat quality in terms of meat lipid oxidation and meat mineral content, and may be replace up to $75 \%$ of commercial broiler feeds with beneficial effects.

\section{INTRODUCTION}

In comparison with beef, mutton and pork, broiler meat consumption has shown an increasing trend across the globe mainly due to affordable prices and high availability. In addition, its consumption has no religious bindings as, in particularly, in the case of beef (Hindus) and pork (Muslims) and has an overall acceptable nutritional profile and taste.

Due to the increasing availability and consumption of broiler meat, consumers have now started showing interest in its micronutrient profile, taste, juiciness and health benefits. Feeding commercial rations has supported the rapid growth rate broilers, but consumers often complain about poor juiciness and taste of chicken meat. Slowing the growth of commercial broilers has shown to improved meat quality and supplementing vegetable waste to slow down their growth rate, supplying only their maintenance requirements, without adding much to the production cost is an emerging trend (Hossain et al., 2013).

Additionally, vegetables are rich nutrient sources, potentially good for supplying essential amino acids, minerals and antioxidants to the birds, comparatively inexpensive, easily available, easy to process 
Raza A, Hussain J, Hussnain F, Zahra F, Mehmood S, Mahmud A, Amjad ZB, Khan MT, Asif M, Ali U, Badar IH, Nadeem M
Vegetable Waste Inclusion in Broiler Diets and its Effect on Growth Performance, Blood Metabolites, Immunity, Meat Mineral Content and Lipid Oxidation Status and pose less risk of disease contamination (Omenka \& Anyasor, 2010). Consumers prefer the meat of broilers exclusively fed with vegetable sources (Mendes, 2003) as they feel it is more tasty, juicy, and tender. However, it should be also considered that vegetable sources contain numerous antinutritive factors (ANF), lower protein quality, lower digestibility and lower biological value compared with animal sources (Dublecz, 2003; Vieira et al., 2003) and can affect meat quality. Diets with vegetables may possibly be nutritionally inferior and broilers fed on such diets may or may not respond positively (Hossain et al., 2013).

Due to changes in life style across the globe, people are becoming more health-conscious, increasing the demand for functional and organic foods. Broiler meat with increased levels of natural antioxidants may be declared as a functional food. Chicken meat is rich in polyunsaturated fatty acids (PUFA), which are more sensitive to free-radical attack, leading to oxidative damage (Arshad et al., 2011). Meat quality is negatively affected when free radicals initiate the oxidation reaction and destroy the normal muscle fiber, accumulating harmful byproducts in the muscle (Brenes et al., 2008). Meat discoloration post mortem is predominantly caused by the oxidation of myoglobin (Faustman et al., 2010). It is assumed that vegetables/ green leafy plants fed to broilers may improve the antioxidant status of meat and reduce the harmful effects of oxidative damage. Hence, this experiment was planned with multiple objectives, in particular, to study the effect of cheapest vegetable wastes available in the nearby market on overall growth performance, immune profile, serum chemistry and, most importantly, meat mineral and antioxidant status of broilers.

\section{MATERIALS AND METHODS}

The study was conducted at the broiler experimental unit, Department of Poultry Production, University of Veterinary and Animal Sciences (UVAS), Ravi Campus, Pattoki, Pakistan.

In total, 100 one-day-old chicks (Cobb-500) were acquired from a local hatchery and fed a conventional diet (standard commercial broiler feed) for the first four weeks. Birds were vaccinated and received medical care according to the standard veterinary practices. At 28 days old, 100 birds with uniform body weight were selected and distributed into five dietary treatments according to a completely randomized design (Steel et al., 1997), with four replicates of five birds each. The treatments consisted of: T1 (100\% commercial feed (CF) + 0\% VW), T2 (75\% CF + 25\% VW), T3 (50\% CF

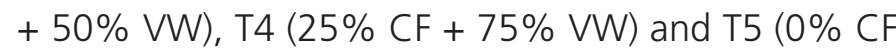
$+100 \% \mathrm{VW})$.

Vegetable waste included alfalfa, spinach and cauliflower (fresh, on equal weight basis) collected in the local market. Representative samples of $10 \mathrm{~g}$ each of vegetable waste (alfalfa, spinach and cauliflower) were collected, stored, and their chemical composition was analyzed (AOAC, 2006). The nutritional composition of different vegetable wastes used in this study are presented in Table 1.

Table 1 - Chemical composition of the vegetable wastes fed with different levels.

\begin{tabular}{lcccc}
\hline Vegetable Waste & Dry Matter (\%) & Crude Protein (\%) & Ash (\%) & Ether Extract (\%) \\
\hline Alfalfa & 28.16 & 19.80 & 9.36 & 2.13 \\
Cauliflower & 11.64 & 10.63 & 6.56 & 1.38 \\
Spinach & 8.10 & 36.40 & 22.33 & 3.30 \\
\hline
\end{tabular}

\section{Housing and Management}

The experimental birds were housed on littercovered floor at a stocking density of $0.0604 \mathrm{~m}^{2}$ per bird. They had free access to feed and water in pan feeders and nipple drinking system, respectively. Standard management practices were applied. House temperature and relative humidity $(\mathrm{RH})$ were maintained at $35 \pm 0.5^{\circ} \mathrm{C}$ and $62 \pm 3 \%$, respectively, for first week after hatch. After that, temperature was gradually decreased until it reached $24^{\circ} \mathrm{C}$ on day 21 with $\mathrm{RH} 65 \%$. A 24-h continuous light schedule was applied throughout the study period.

\section{Growth performance}

Birds, feed offer and feed residues were recorded to calculate feed intake (g) and weight gain ( $\mathrm{g}$ ) on weekly basis. Feed efficiency was calculated as the ratio $(\mathrm{g} / \mathrm{g})$ between weight gain (WG) and feed intake (FI). Mortality (if any) was recorded on daily basis to calculate percent mortality. At 49 days of age, eight birds (2 birds/replicate) were randomly selected from each treatment. Birds were individually weighed, and tagged on the shanks according to dietary groups. The birds were then transported to the Department of Meat Science and Technology, UVAS, Lahore, and manually 
Raza A, Hussain J, Hussnain F, Zahra F, Mehmood S, Mahmud A, Amjad ZB, Khan MT, Asif M, Ali U, Badar IH, Nadeem M
Vegetable Waste Inclusion in Broiler Diets and its Effect on Growth Performance, Blood Metabolites, Immunity, Meat Mineral Content and Lipid Oxidation Status slaughtered according to the Halal method. Broilers were kept off-feed for four hours prior to slaughter.

\section{Serum chemistry and antibody response}

Blood biochemistry and antibody response analyses were conducted at the Quality Operations Laboratory and University Diagnostic Lab, UVAS, Lahore.

For blood biochemistry analyses, $5 \mathrm{~mL}$ blood was collected from the jugular vein of three birds per treatment into a vacutainer tube with no anticoagulant. The blood was centrifuged at 3,000 rpm for $15 \mathrm{~min}$ and the serum was separated and stored at $-20^{\circ} \mathrm{C}$ until analyses. The serum was then thawed, and the concentrations of cholesterol, triglycerides, glucose, total protein, albumin, globulin, uric acid and creatinine were determined in a spectrophotometer using commercially available kits at specific wave lengths. Antibody titers against Newcastle Disease $(\mathrm{HI}$ test; Allan \& Gough 1974), Infectious Bronchitis (ELISA; Piela et al., 1984), Salmonella Pullorum (HA test; Minga \& Wray 1992) and Mycoplasma gallisepticum (ELISA; Piela et al., 1984) were determined.

\section{Meat mineral profile and lipid oxidation status}

The analysis of meat mineral profile was conducted at the Department of Environmental Science, UVAS, Lahore, while lipid oxidation tests of the meat samples were conducted at Lipid Chemistry lab, Department of Dairy Technology, UVAS, Ravi Campus, Pattoki.

Breast meat samples, weighing $50 \mathrm{~g}$, were collected from five birds per treatment and stored at $-20^{\circ} \mathrm{C}$. Samples were then analyzed for macro and trace minerals, including calcium (flame photometer; Tuba, 2015), phosphorus (spectrophotometer; Adeyeye, 2009), magnesium (atomic absorption spectrophotometer; Adeyeye, 2009), sodium (flame photometer; Tuba, 2015), manganese and zinc (atomic absorption spectrophotometer; Adeyeye, 2009) and iron (atomic absorption spectrophotometer; Kilic, 2002).

In addition, breast meat samples, weighing 100$125 \mathrm{~g}$, were collected from each treatment and stored at $-20^{\circ} \mathrm{C}$ for 45 days. After 45 days, samples were analyzed for total phenolic contents (Al-Farsi et al. 2005), total flavonoid contents (Schieber et al., 2003) and thio-barbituric acid values (AOCS, 1995).

\section{Statistical Analysis}

The collected data were analyzed by one-way analysis of variance according to a completely randomized design (Steel et al., 1997) in SAS 9.4 statistical package (SAS Institute, 2013). Means were compared by Duncan's Multiple Range (DMR) test (Duncan, 1955).

\section{RESULTS AND DISCUSSION}

\section{Growth performance}

In the present study, initial body weight (28 days of age) was not significantly different among treatments (Table 2), indicating that birds presented uniform body weight at the start of experiment. Birds fed $100 \%$ CF + $0 \% \mathrm{VW}(\mathrm{T} 1)$ showed the highest final body weight and weight gain, and the best feed efficiency, followed by those fed $75 \%$ CF+ 25\% VW (T2), 50\% CF + 50\% VW (T3), $25 \% \mathrm{CF}+75 \% \mathrm{VW}(\mathrm{T} 4)$ and $0 \% \mathrm{CF}+100 \% \mathrm{VW}$ (T5), respectively (Table 2 ). The gradual worsening of live performance parameters obtained as VW dietary levels increased may be attributed to the nutritional variation of the diets, as VW contains high fiber and low nutrient levels (Livingstone et al., 1980; Mustafa \& Baurhoo, 2017). Therefore, high VW inclusion levels in diet resulted in lower nutrient intake and retarded growth. In addition, high fiber dietary content also causes poor feed efficiency (Thacker \& Petri, 2009). The results of the present study are consistent with those reported by Westendorf \& Myer (2009), who also observed slow broiler growth rate when vegetable waste was added to the diet. In a similar study, Oghenebrorhie \& Oghenesuvwe (2016) obtained comparable final body weight $(p>0.05)$ but worse feed efficiency when $10 \%$ of a conventional feed was replaced with vegetable sources. Bhuiyan et al. (2012a, b) fed broilers with diets supplemented with vegetable sources, but did not observe any significant differences in the growth performance. Onu (2010), on the other hand, obtained higher final body weight with the inclusion of $25 \%$ vegetable waste compared to control diet in broilers. Tasirnafas et al. (2015) supplemented ostrich chick diets with $0,10,20$, or $30 \%$ vegetable waste, and obtained found significantly higher final body weight and weight gain in the $20 \%$ and $30 \%$ treatments as compared to control group.

Surprisingly, no mortality was observed in any of the treatment groups (Table 2) during the entire experimental period, which clearly indicates that the diets had no adverse effects on the birds' health status. Oghenebrorhie \& Oghenesuvwe (2016) also reported no mortality during the entire experimental phase when broilers were fed diets with $5 \%, 10 \%$ and $20 \%$ of a vegetable source. 
Raza A, Hussain J, Hussnain F, Zahra F, Mehmood S, Mahmud A, Amjad ZB, Khan MT, Asif M, Ali U, Badar IH, Nadeem M
Vegetable Waste Inclusion in Broiler Diets and its Effect on Growth Performance, Blood Metabolites, Immunity, Meat Mineral Content and Lipid Oxidation Status

Table $\mathbf{2}$ - Growth performance of broilers fed increasing levels of vegetable waste (means \pm SEM).

\begin{tabular}{|c|c|c|c|c|}
\hline Treatments & $\begin{array}{l}\text { Initial weight } \\
\text { (28 days) } \\
\text { (g) }\end{array}$ & $\begin{array}{l}\text { Final weight } \\
\text { (at } 49 \text { days) } \\
\text { (g) }\end{array}$ & $\begin{array}{l}\text { Weight Gain } \\
\text { (g) }\end{array}$ & Feed Efficiency ${ }^{\S}$ \\
\hline Control $\left(100 \% \mathrm{CF}^{+}+0 \% \mathrm{WV}^{\$}\right)$ & $1301.90 \pm 2.50$ & $3089.45 \pm 4.08^{\mathrm{a}}$ & $1787.55 \pm 4.06^{a}$ & $0.42 \pm 0.001^{a}$ \\
\hline $75 \% \mathrm{CF}^{+}+25 \% \mathrm{VW}^{\$}$ & $1304.20 \pm 2.32$ & $2708.35 \pm 16.33^{b}$ & $1404.15 \pm 15.81^{b}$ & $0.24 \pm 0.006^{b}$ \\
\hline $50 \% \mathrm{CF}^{+}+50 \% \mathrm{VW}^{\$}$ & $1305.90 \pm 2.50$ & $2287.90 \pm 11.02^{c}$ & $982.00 \pm 11.22^{c}$ & $0.11 \pm 0.001^{c}$ \\
\hline $25 \% \mathrm{CF}^{+}+75 \% \mathrm{VW}^{\$}$ & $1302.20 \pm 2.32$ & $1784.30 \pm 12.53^{d}$ & $482.10 \pm 13.62^{d}$ & $0.03 \pm 0.005^{d}$ \\
\hline $0 \% \mathrm{CF}^{+}+100 \% \mathrm{VW}^{\$}$ & $1310.65 \pm 2.58$ & $1342.50 \pm 3.47^{e}$ & $31.85 \pm 1.66^{e}$ & $0.00 \pm 0.00^{e}$ \\
\hline$p$-value & 0.0857 & $<0.0001$ & $<0.0001$ & $<.0001$ \\
\hline
\end{tabular}

*Means followed by different superscripts indicate significant differences $(p \leq 0.05)$ among treatments.

${ }^{+} \mathrm{CF}$ (Commercial Feed)

sVW (Vegetable Waste)

sFeed efficiency based only on commercial feed intake

\section{Serum Chemistry}

Total protein and globulin serum contents were significantly $(p \leq 0.05)$ higher in the control group, followed by a gradual decrease as vegetable waste supplementation levels increased. No significant differences ( $p>0.05)$ were observed in serum cholesterol, triglycerides, glucose, albumin, uric acid or creatinine levels among treatments (Table 3). The higher total protein and globulin contents obtained in the broilers of the control group may be attributed to their high growth rate (Table 2 ) as growth rate is associated with higher concentration of proteins in serum (Kapelanski et al., 2004; Krames, 2010). Moreover, the reduced total protein and globulin contents as the dietary vegetable waste level increased may be due to the defatted part of vegetables, due to their high fiber content (25.24\%) and lower CP content compared with the commercial feed, thereby decreasing absorption in the small intestine (Zhang et al., 2009) resulting in malabsorption and a decrease in total protein and globulin contents in the blood serum. Zhang et al. (2009) also found a trend of higher serum total protein levels in 21- and 42-d-old broilers fed a diet supplemented with dry ginger root compared with the control diet. However, Onu (2010) did not observe any differences in serum total protein, globulin, albumin, glucose, uric acid, triglyceride and creatinine levels between broilers fed diets supplemented with vegetable waste or a control diet, indicating that some serum biochemistry parameters, such as glucose, total cholesterol, and albumin are not necessarily dependent on vegetable waste inclusion levels (Sadeghi et al., 2016).

Table 3 - Serum chemistry of broilers fed increasing levels of vegetable waste (means \pm SEM).

\begin{tabular}{|c|c|c|c|c|c|c|c|c|}
\hline Treatments & $\begin{array}{c}\text { Cholesterol } \\
(\mathrm{mg} / \mathrm{dL})\end{array}$ & $\begin{array}{c}\text { Triglycerides } \\
(\mathrm{mg} / \mathrm{dL})\end{array}$ & $\begin{array}{l}\text { Glucose } \\
\text { (mg/dL) }\end{array}$ & $\begin{array}{l}\text { Total Protein } \\
(\mathrm{g} / \mathrm{dL})\end{array}$ & $\begin{array}{l}\text { Albumin } \\
(\mathrm{g} / \mathrm{dL})\end{array}$ & $\begin{array}{l}\text { Globulin } \\
\text { (g/dL) }\end{array}$ & $\begin{array}{l}\text { Uric Acid } \\
\text { (mg/dL) }\end{array}$ & $\begin{array}{c}\text { Creatinine } \\
(\mathrm{mg} / \mathrm{dL})\end{array}$ \\
\hline Control $\left(100 \% C^{+}+0 \% V^{+}\right)$ & $120.00 \pm 36.77$ & $40.00 \pm 20.07$ & $188.33 \pm 33.62$ & $2.10 \pm 0.47^{a}$ & $0.30 \pm 0.15$ & $1.80 \pm 0.40^{a}$ & $4.30 \pm 1.55$ & $0.27 \pm 0.03$ \\
\hline $75 \% \mathrm{CF}^{+}+25 \% \mathrm{VW}^{\$}$ & $104.67 \pm 22.24$ & $10.30 \pm 7.86$ & $254.00 \pm 38.43$ & $2.03 \pm 0.07^{a}$ & $0.27 \pm 0.09$ & $1.77 \pm 0.12^{\mathrm{a}}$ & $4.43 \pm 1.55$ & $0.20 \pm 0.06$ \\
\hline $50 \% \mathrm{CF}^{+}+50 \% \mathrm{VW}^{\$}$ & $78.33 \pm 14.08$ & $10.33 \pm 4.06$ & $170.00 \pm 21.79$ & $1.60 \pm 0.36^{\mathrm{ab}}$ & $0.47 \pm 0.07$ & $1.13 \pm 0.30^{\mathrm{ab}}$ & $2.30 \pm 0.51$ & $0.30 \pm 0.06$ \\
\hline $25 \% \mathrm{CF}^{+}+75 \% \mathrm{VW}^{\$}$ & $99.00 \pm 4.00$ & $12.33 \pm 6.71$ & $171.33 \pm 16.05$ & $2.07 \pm 0.52^{\mathrm{a}}$ & $0.70 \pm 0.25$ & $1.37 \pm 0.43^{a}$ & $5.67 \pm 1.03$ & $0.70 \pm 0.09$ \\
\hline $0 \% \mathrm{CF}^{+}+100 \% \mathrm{VW}^{\$}$ & $86.00 \pm 15.10$ & $35.67 \pm 19.65$ & $160.67 \pm 0.88$ & $0.53 \pm 0.09^{b}$ & $0.30 \pm 0.06$ & $0.23 \pm 0.03^{b}$ & $6.13 \pm 0.20$ & $0.27 \pm 0.09$ \\
\hline$p$-value & 0.6850 & 0.4508 & 0.1510 & 0.0493 & 0.2454 & 0.0242 & 0.2050 & 0.5024 \\
\hline
\end{tabular}

*Means followed by different superscripts indicate significant differences $(p \leq 0.05)$ among treatments.

+ CF (Commercial Feed)

sVW (Vegetable Waste)

\section{Antibody Response}

In the present study, antibody titers against Newcastle Disease (ND), Infectious Bronchitis (IB) and Mycoplasma gallisepticum (MG) were not influenced $(p>0.05)$ by the dietary treatments. All treatment groups were negative for Salmonella Pullorum (SP) (Table 4). The lack of significant differences in immune response parameters among different dietary treatments suggests that reducing the intake of commercial feeds by feeding higher concentrations of vegetable waste did not negatively affect the broilers' immune status (Table 4). Zhang et al. (2009) observed reduced growth rate due to lower nutrient intake, but no differences in the immune profile broilers fed ginger root. Yu et al. (2009) did not find any significant differences in the immune response of broilers receiving vegetables with their diet, and concluded that the addition of either 1 or $3 \%$ level in the diet has no beneficial effect on 
Table 4 - Antibody response of broilers fed increasing levels of vegetable waste (means \pm SEM).

\begin{tabular}{lcccc}
\hline Treatments & ND titer & IB titer & SP detection & MG detection \\
\hline Control $\left(100 \% \mathrm{CF}^{+}+0 \% \mathrm{WV}^{\text {s}}\right)$ & $3.67 \pm 1.20$ & $5.69 \pm 4.69$ & Negative & $0.40 \pm 0.17$ \\
$75 \% \mathrm{CF}^{+}+25 \% \mathrm{VW}^{s}$ & $4.33 \pm 0.88$ & $1.00 \pm 0.00$ & Negative & $0.11 \pm 0.01$ \\
$50 \% \mathrm{CF}^{+}+50 \% \mathrm{VW}^{s}$ & $6.67 \pm 0.88$ & $112.51 \pm 40.74$ & Negative & $0.12 \pm 0.00$ \\
$25 \% \mathrm{CF}^{+}+75 \% \mathrm{VW}^{s}$ & $6.33 \pm 0.33$ & $184.63 \pm 183.63$ & Negative & $0.15 \pm 0.03$ \\
$0 \% \mathrm{CF}^{+}+100 \% \mathrm{VW}^{s}$ & $7.00 \pm 0.58$ & $37.50 \pm 36.50$ & Negative & $0.017 \pm 0.05$ \\
\hline$p$-value & 0.0591 & 0.5268 & Negative & 0.1562 \\
\hline
\end{tabular}

*Means followed by different superscripts indicate significant differences $(p \leq 0.05)$ among treatments.

${ }^{+}$CF (Commercial Feed)

sVW (Vegetable Waste)

the antibody production in broilers (Jafari et al., 2008). Moreover, blood biochemistry values obtained in the present study were within the normal range for chickens i.e., blood glucose levels in the range 200 to $500 \mathrm{mg} / \mathrm{dL}$, blood protein 2.5 to $4.5 \mathrm{~g} / \mathrm{dL}$, albumin and globulin in the range of 0.5 to $1.8 \mathrm{~g} / \mathrm{dL}$ (Thrall, 2007).

\section{Meat Mineral Profile}

Magnesium (Mg) levels were significantly $(p \leq 0.05)$ higher in the meat of birds fed the control diet, whereas sodium, phosphorus, calcium, zinc, manganese and iron levels were not affected by the dietary treatments (Table 5). After potassium, magnesium is second most abundant mineral present in the muscle tissue (Suttle, 2010). The birds in the control group showed the highest weight gain weight (Table 2) and highest Mg meat content, suggesting the higher Mg level of the commercial feed resulted in higher Mg deposition. In line with these findings, it was reported that supplementation of vegetable sources during the growing phase may result in lower mineral contents in meat of broilers (Teeter \& Deyhim, 1994). Vegetable waste is usually considered as rich source of minerals (Omenka \& Anyasor, 2010). However, in the present study, no significant differences were observed for most of the evaluated minerals. Commercial poultry

Table 5 - Meat mineral profile of broilers fed increasing levels of vegetable waste (means \pm SEM).

\begin{tabular}{|c|c|c|c|c|c|c|c|}
\hline Treatments & $\mathrm{Na}(\mathrm{mg} / \mathrm{L})$ & $\mathrm{P}(\mathrm{mg} / \mathrm{L})$ & $\mathrm{Mg}(\mathrm{mg} / \mathrm{L})$ & $\mathrm{Ca}(\mathrm{mg} / \mathrm{L})$ & $\mathrm{Mn}(\mathrm{mg} \backslash \mathrm{L})$ & $\mathrm{Zn}(\mathrm{mg} / \mathrm{L})$ & $\mathrm{Fe}(\mathrm{mg} / \mathrm{L})$ \\
\hline Control $\left(100 \% \mathrm{CF}^{+}+0 \% \mathrm{WV}\right)$ & $577.50 \pm 91.39$ & $505.83 \pm 7.41$ & $134.75 \pm 0.38^{a}$ & $5159.17 \pm 45.51$ & Zero & $4.33 \pm 0.85$ & $31.92 \pm 0.98$ \\
\hline $75 \% \mathrm{CF}^{+}+25 \% \mathrm{VW}^{\$}$ & $456.67 \pm 18.78$ & $462.50 \pm 13.77$ & $132.42 \pm 0.46^{\mathrm{ab}}$ & $5051.67 \pm 43.21$ & Zero & $4.83 \pm 1.46$ & $38.08 \pm 0.87$ \\
\hline $50 \% \mathrm{CF}^{+}+50 \% \mathrm{VW}^{\$}$ & $420.00 \pm 6.61$ & $449.17 \pm 23.02$ & $131.00 \pm 0.38^{b c}$ & $5162.50 \pm 35.56$ & Zero & $4.25 \pm 1.44$ & $42.33 \pm 6.21$ \\
\hline $25 \% \mathrm{CF}^{+}+75 \% \mathrm{VW}^{\$}$ & $429.17 \pm 28.22$ & $460.83 \pm 14.53$ & $129.75 \pm 1.51^{\mathrm{cd}}$ & $4964.17 \pm 119.18$ & Zero & $3.42 \pm 1.20$ & $38.17 \pm 4.41$ \\
\hline $0 \% \mathrm{CF}^{+}+100 \% \mathrm{VW}^{\$}$ & $759.17 \pm 172.16$ & $470.83 \pm 4.41$ & $128.41 \pm 0.36^{d}$ & $4683.33 \pm 267.16$ & Zero & $5.17 \pm 1.42$ & $27.92 \pm 1.10$ \\
\hline$p$-value & 0.0980 & 0.1287 & 0.0014 & 0.1492 & Zero & 0.8949 & 0.0940 \\
\hline
\end{tabular}

*Means followed by different superscripts indicate significant differences $(p \leq 0.05)$ among treatments.

${ }^{+}$CF (Commercial Feed)

sVW (Vegetable Waste)

feeds typically contain mineral levels to supply the birds' requirements (Leeson \& Summers, 2005). Therefore, the obtained results may be correlated as the birds fed the diets with higher VW supplementation had lower feed intake and vice versa, resulting in comparable mineral contents among all dietary treatments.

\section{Meat Lipid Oxidation}

The replacement of the commercial feed with increasing levels of vegetable waste had a marked effect on the meat antioxidant capacity of broilers (Table 6). Vegetable waste inclusion improved both total phenolic contents (TPC) and total flavonoid contents (TFC) in the meat as the highest TPC and TFC were determined in the meat of birds fed $100 \% \mathrm{VW}$, followed by those of fed diets containing 75\% CF + $25 \% \mathrm{VW}, 50 \% \mathrm{CF}+50 \% \mathrm{VW}$ and $75 \% \mathrm{CF}+25 \% \mathrm{VW}$ and $100 \mathrm{CF}+0 \% \mathrm{VW}$ (Table 6). This increase in meat TPC and TFC contents may be explained by the fact that vegetables are rich sources of carotenoids, which have potent antioxidant capacity (Osterlie \& Lerfall, 2005) and are mainly responsible for the protection against oxidative damage at cellular level (DiMascio et al., 1989; Rao \& Agarwal, 1999). Carotenoids are also the main pigments present in meat, and provide resistance against rancidity, allowing long-term meat storage (Peters et al., 2011).

The thiobarbituric acid value (TBA value) is an indicator of meat oxidation status and it also used to describe the shelf life of foods. Low meat TBA values 
Table 6 - Meat lipid oxidation of broilers fed increasing levels of vegetable waste (means $\pm S E M$ ).

\begin{tabular}{lccc}
\hline Treatments & Total phenolic content (TPC) mg/g GAE & Total flavonoid content (TFC) mg/g QE & Thiobarbituricacid value (TBA) \\
\hline Control $\left(100 \% \mathrm{CF}^{+}+0 \% \mathrm{WV}^{\$}\right)$ & $43.88 \pm 0.56^{\mathrm{e}}$ & $27.98 \pm 2.23^{\mathrm{e}}$ & $0.0176 \pm 0.0012^{\mathrm{a}}$ \\
$75 \% \mathrm{CF}^{+}+25 \% \mathrm{VW}^{\$}$ & $62.26 \pm 0.33^{\mathrm{d}}$ & $132.67 \pm 4.06^{\mathrm{d}}$ & $0.0123 \pm 0.0012^{\mathrm{b}}$ \\
$75 \% \mathrm{CF}^{+}+25 \% \mathrm{VW}^{\$}$ & $73.52 \pm 0.29^{\mathrm{c}}$ & $158.19 \pm 8.96^{\mathrm{c}}$ & $0.006 \pm 0.0008^{\mathrm{c}}$ \\
$75 \% \mathrm{CF}^{+}+25 \% \mathrm{VW}^{\$}$ & $80 \pm 0.50^{\mathrm{b}}$ & $244.08 \pm 8.25^{\mathrm{b}}$ & $0.004 \pm 0.0005^{\mathrm{c}}$ \\
$0 \% \mathrm{WV}^{\$}+100 \% \mathrm{WW}^{\$}$ & $93.26 \pm 0.32^{\mathrm{a}}$ & $295.07 \pm 6.94^{\mathrm{a}}$ & $0.0008 \pm 0.0001^{\mathrm{d}}$ \\
\hline$p$-value & $<0.0001$ & $<0.0001$ & $<0.0001$ \\
\hline
\end{tabular}

*Means followed by different superscripts indicate significant differences $(p \leq 0.05)$ among treatments.

+ CF (Commercial Feed)

sVW (Vegetable Waste)

indicate greater antioxidant status and storage stability. The treatment groups which meat presented higher phenolic and flavonoid contents had lower TBA values. In present study, the highest TBA values were found in control group, and steadily decline as the dietary level of waste vegetable increased (Table 6). These results may be attributed to the activity of antioxidants found in abundant quantity in vegetable sources (Wang \& Yang, 2010) as compared to the commercial diet. Similarly, Naeem \& Khan (2013) also reported higher antioxidant activity after supplementation of plant origin ingredients in diet.

\section{CONCLUSIONS}

The replacement of a commercial diet by increasing levels of vegetable waste had negatively affected broiler growth performance as broiler weight gain decreased as dietary vegetable waste inclusion increased. Meat mineral profile was not influenced by vegetable waste inclusion levels, except for magnesium, which level also decreased as vegetable waste inclusion increased. Broiler immune profile of was not affected by the treatments. The most significant change was observed in meat lipid oxidation status, which improved with increasing dietary vegetable waste levels. The highest vegetable waste level promoted the best meat antioxidant status, as demonstrated by the highest total phenolic and flavonoid contents and the lowest TBA value. Therefore, it may be concluded that meat quality, particularly in terms of shelf life, may be enhanced by the dietary inclusion of vegetable waste, due to a significant reduction in the probability of rancidity.

\section{ACKNOWLEDGEMENTS}

The authors gratefully acknowledge the administration of A block Ravi Campus Pattoki, University of Veterinary and Animal Sciences, Lahore.

\section{CONFLICT OF INTEREST}

No potential conflict of interest was found by the authors.

\section{REFERENCES}

Adeyeye El. Comparative study on the characteristics of egg shells of some bird species. Bulletin of the Chemical Society of Ethiopia 2009;23(2):159-166.

Allan HW, Gough ER. A standard hemagglutination inhibition test for Newcastle disease (2) Vaccination and challenge. The Veterinary Record 1974;95(7):147-149.

AOAC. Official method of analysis. $18^{\text {th }}$ ed. Washington: Association of Official Analytical Chemist; 2006.

Arshad MS, Anjum FM, Asghar A, Khan MI, Yasin M, Shahid M, et al. Lipid stability and antioxidant profile of microsomal fraction of broiler meat enriched with $\alpha$-lipoic acid and $\alpha$-tocopherol acetate. Journal of Agricultural and Food Chemistry 2011;59(13):7346-7352.

Bhuiyan MM, Clatworthy G, lji PA. Vegetable protein diets are adequate but broiler chickens prefer animal protein diets [CD-ROM]. World's Poultry Science Journal 2012a;68(Suppl. 1).

Bhuiyan, MM, Hossain, MA, lji PA. Preference of broiler chickens for animal and vegetable protein diets. Australasian Medical Journal 2012b;5:657.

Brenes A, Viveros A, Goni I, Centeno C, Sayago-Ayerdy SG, Arija I, ET AL. Effect of grape pomace concentrate and vitamin $E$ on digestibility of polyphenols and antioxidant activity in chickens. Poultry Science 2008;87(2):307-316.

DiMascio P, Kaiser S, Sies S. Lycopene as the most effective biological carotenoid singlet oxygen quencher. Archives of Biochemistry and Biophysics 1989;274:532-538.

Dublecz K. Poultry nutrition without animal protein sources. Allattenyesztes es Takarmanyozas 2003;52(5):479-489.

Duncan DB. Multiple range and multiple F tests. Biometrics 1955;11(1):142.

Faustman C, Sun Q, Mancini R, Suman SP. Myoglobin and lipid oxidation interactions: Mechanistic bases and control. Meat Science 2010;86(1):86-94

Hossain MA, Islam AF, Iji PA. Growth responses, excreta quality, nutrient digestibility, bone development and meat yield traits of broiler chickens fed vegetable or animal protein diets. South African Journal of Animal Science 2013;43:208-218. 
Raza A, Hussain J, Hussnain F, Zahra

Jafari R, Razi M, Ghorbanpoor M, Marashian S. Effect of dietary garlic on immune response of broiler chicks to live Newcastle disease vaccine. Pakistan Journal of Biological Sciences 2008;14:1848-1851.

Kapelanski W, Grajewska S, Bocian M, Dybala J, Jankowiak H. Changes in blood biochemical indicators during fattening of the high-lean pigs. Animal Science Papers and Reports 2004;22:443-449.

Kilic Z, Acarb O, Ulasan M, Ilim M. Determination of lead, copper, zinc, magnesium, calcium and iron in fresh eggs by atomic absorption spectrometry. Food Chemistry 2002;76:107-116.

Krames. Total protein and A/G ratio tests. Mount Nittany Medical Center 2010;814:231-700.

Leeson S, Summers JD. Commercial poultry nutrition. Nottingham: Nottingham University Press; 2005. p.71.

Livingstone R, Baird BA, Atkinson T. Cabbage (Brassica oleracea) in the diet of growing-finishing pigs. Animal Feed Science and Technology 1980;5:69-75

Minga UM, Wray C. A disc ELISA for the detection of Salmonella group D antibodies in poultry. Research of Veterinary Science 1992;52:384-386.

Mendes AA. Rastreabilidade official avícola em discussão. Dipemar; 2003. Available from: http://www.dipemar.com.br/carne/315/materia_ especial_carne.htm.

Mustafa AF, Baurhoo B. Evaluation of dried vegetables residues for poultry: II. Effects of feeding cabbage leaf residues on broiler performance, ileal digestibility and total tract nutrient digestibility. Poultry Science 2017;96(3):681-686.

Naeem F, Khan SH. Purslane (Portulaca oleracea L.) as phytogenic substance: a review. Journal of Herbs, Spices \& Medicinal Plants 2013;19:216-232.

Oghenebrorhie O, Oghenesuvwe O. Performance and haematological characteristics of broiler finisher fed Moringa oleifera leaf diets. Journal of Northeast Agriculture University 2016;23(1):28-34

Omenka RO, Anyasor GN. Vegetable-based feed formulation on poultry meat quality. African Journal of Food, Agriculture, Nutrition and Development 2010;10(1):2001-2010.

Onu PN. Evaluation of two herbal spices as feed additives for finisher broilers. Biotechnology in Animal Husbandry 2010;26:383-392.

Osterlie M, Lerfall J. Lycopene from tomato products added minced meat: Effect on storage quality and colour. Food Research International 2005;38:925-929.

Peters A, Magdeburg S, Dalbey K. The carotenoid conundrum: improved nutrition boosts carotenoid levels but not immune benefits of carotenoid supplementation. Oecologia 2011;166:35-43.

Piela TH, Gulka CM, Yates VJ Chang PW. Use of egg yolk in serological tests (ELISA and $\mathrm{HI}$ ) to detect antibody to Newcastle disease, infectious bronchitis and Mycoplasma gallisepticum. Avian Diseases 1984;28(4):877-83.
Rao AV, Agarwal S. Role of lycopene as antioxidant carotenoid in the prevention of chronic diseases: a Review. Food \& Nutrition Research 1999;19:305-323.

Sadeghi G, Karimi A, Shafeie F, Vaziry A, Farhadi D. The Effects of purslane (Portulacaoleracea L.) powder on growth performance, carcasscharacteristics, antioxidant status, and blood metabolites in broiler chickens. Livestock Science 2016;184:35-40.

SAS Institute. SAS user's guide: statistics. Release 9.4. Cary: SAS Institute; 2013.

Steel RGD, Torrie JH, Dickie DA. Principles and procedures of statistics. A biometric approach. $3^{\text {rd }}$ ed. Toronto: McGraw-Hill Book Publishing;1997. p.633.

Suttle NF. Magnesium. In: Suttle, NF, editor. Mineral nutrition of livestock. $4^{\text {th }}$ ed. Wallingford: CABI Publisher; 2010; p.92-121.

Tasirnafas ME, Seidavi AR, Rasouli B, Kawka M. Effect of vegetable wastage and energy in ostrich chick diet on performance and hematology. Tropical Animal Health and Production 2015;47:1017-1026.

Teeter RG, Deyhim F. Cheaper chicken feeds? Feed International $1994 ; 15(6): 22-25$

Thacker PA, Petri D. Nutrient digestibility and performance of broiler chickens fed regular or green canola biodiesel press cakes produced using a micro-scale process. Journal of the Science of Food and Agriculture 2009;89:1307-1313.

Thrall MA. Hematologia e bioquímica clínica veterinária. São Paulo: Roca; 2007. p. 582.

Tuba K, Asad KT, Majid M, Sara A. Analysis of essential elements in commercially important Lobster species collected from coastal areas of Karachi city, Pakistan. Journal of Pharmacy Nutrition Science 2015;5:103-113.

Vieira SL, Lima IL, Borges CAQ, Fernandes LM, Quadros VR. Broiler utilization of vegetarian diets. Poultry Science 2003;82:38.

Wang CQ, Yang GQ. Betacyanins from Portulaca oleracea L. ameliorate cognition deficits and attenuate oxidative damage induced by $d$-galactosein the brains of senescent mice. Phytomedicine 2010;17:527-532.

Westendorf, ML, Myer RO. Feeding food waste to swine [cited 2010 Aug 18]. Gainesville: University of Florida; 2009. Available from: http://edis. ifas.ufl.edu/an143.

Yu C, Lai K, Yang J, Chiang J, Lu C, Wu C, et al. Quercetin inhibited murine leukemia WEHI-3 cells in vivo and promoted immune response. Phytotherapy Research 2009;24:163-168.

Zhang GF, Yang ZB, Wang Y, Yang WR, Jiang SZ, Gai GS. Effects of ginger root (Zingiber officinale) processed to different particle sizes on growth performance, antioxidant status, and serum metabolites of broiler chickens. Poultry Science 2009;88:2159-2166. 
